\title{
Systematic and Abundance of Ground Beetles (Carabidae: Coleoptera) From District Poonch Azad Kashmir, Pakistan
}

\author{
Junaid Rahim 1 , Muhammad Rafique Khan ${ }^{2}$, Naila Nazir ${ }^{3}$ \\ ${ }^{I_{23} 4}$ Department of Entomology, University of Poonch Rawalakot, Azad Jammu Kashmir, Pakistan
}

\begin{abstract}
Present study was conducted during 2010-2012 dealing with the exploration of carabid fauna and study of their systematic from district Poonch of Azad Kashmir, Pakistan. Carabid beetles were collected with the help of pitfall traps and identified up to specie level with the help of available literature. We identified five species under three genera belonging to 3 sub-families. These sub families are Licininae, Carabinae, Brachininae and the species are Carabus caschmirensis, Chlaenius quadricolar, Pheropsophus sobrinus, Chlaenius laticollis, and Chlaenius hamifer. Carabus cashmirensis was the most abundant species. It was followed by Chlaenius quadricolar, Pheropsophus sobrinus, Chlaenius laticollis, and Chlenius hamifer.
\end{abstract}

Key words: Abundant, Bio-indicator, Carabidae, Poonch, Systematics

\section{Introduction}

Poonch district is of subtropical high land type to temperate area of southern Azad Kashmir receives an average rainfall of $1400-1800 \mathrm{~mm}$ annually. The temperature ranges from $2 \mathrm{C}^{\circ}$ to $38 \mathrm{C}^{\circ}$ during extreme winter it falls below $0 \mathrm{C}^{\circ}$. Some of major plants as apple, some citrus, walnut, apricot and many others along with thick mixed forests of evergreen pine, deodar, blue pine cedar trees and fir are present in study area. Surveyed area hosts the family Carabidae while an estimation of 40,000 species throughout the world [1]. Ground beetles occurred commonly in vegetated lands, field edges, and selected areas with in crop fields. Beetles are considered as indicators of environmental changes in temperate zones and important biological control agent in agroecosystem ([2], [3], [4] and are effective agents for indicating geographical changes as they were highly sensitive to the effect of landscape changes, such as fragmentation [5], [6] [7]. The majority of species have been observed as primarily predatory feeding on other insects and related organisms. Pest status of family Carabidae have little importance feed on seeds of oats, barley, wheat, corn but damage is negligible [2]. Several ground beetle species are phytophagous and feed on the seeds of troublesome weeds species including common ragweed, common lamb's quarters and giant foxtail [8] and thus help to regulate weed populations [9]. Some recent studies revealed that physiology of carabid bettles was adversely affected by the accumulation of toxic metals [10], [11].

Biotic and abiotic factors of environment such as soil moisture, soil type, predation moisture have greater impact on population of carabid bettles [2]. A few species have also been observed to detect chemical cues from springtails, mollusks and aphids [12]. They capture and consume a wide assortment of soil dwelling insects, including caterpillars, wireworms, maggots, ants, aphids and slugs.

Systematics of carabid beetles is stable and they are taxonomically well known, their impact on agriculture is beneficial and their ecology has been widely studied [12]. The taxonomy of the family Carabidae is based exclusively on adults [13], however carabid larvae possess good structural features and could be used to test phylogenetic hypotheses based study of adults [14]. Carabidae because of their importance have been exposed from all the areas of the world. [15] presented the distribution of 348 species of ground beetles belonging to 83 genera in south Dobrudzha, Bulgaria. [16] recorded 57 species of Ground beetles form crops in Turkey. [17] listed 43 species of Carabid beetle from apple orchards and alfalfa fields of Iran. Beside the work done by [18], [19] the carabids have been largely neglected in Pakistan and Azad Jammu \& Kashmir.

Keeping in view such a great importance of carabid beetles as the bioindicators of the well being of environment and their role in soil fertility and predators of the harmful insects this study was designed to investigate the systematics and abundance of the family Carabidae from district Poonch of Azad Kashmir.

\section{Materials and Methods}

\subsection{Collection Localities}

Carabid beetles were collected fortnightly during 9:30 pm to 4:30 am from ten localities of district Poonch. The localities visited include Datot, Topa, Singola, Khai-Gala, Bunjosa, Hussainkot, Rawalakot, Alisojal, Hajira and Abasspur (Fig I\&II). The localities were selected depending on the road links available and at least 10-15 kilometers apart from each other and the maximum area of each locality was covered during the sampling from mid April 2010 to mid October 2012. In this way data for whole season was taken. 2.2 


\section{Collection}

Different spots in visited localities were selected such as, field crops, orchards, residential areas, lawns of the houses, grazing fields, under logs, among rocks, valleys, mountain peaks. Carabid beetles were collected with the help of pitfall traps. Large plastic pots of different sizes with smooth steep sides were used as traps. Holes were digged in the soil in such a way that the rim of the pots remains at the ground surface level. In pitfall traps tomato ketchup was used to attract and to catch the beetles, fallen beetles were taken out and washed with warm water to clean them.

\subsection{Killing and Preservation}

Beetles were thereafter killed by placing them in Cyanide bottle for 6 hours. Collected specimens were brought to the entomological laboratory where they were stretched through specially made non-corrosive insect pins, after 24 hours dried specimens were transferred in the wooden entomological boxes and naphthalene balls and camphor crystals were mounted in them. Identified specimens are kept in Entomological laboratory, Faculty of Agriculture, University of Azad Jammu and Kashmir. Collection, stretching, pinning, labeling and preservation methods were followed after [20].

\subsection{Identification}

The collected specimens were identified up to the species level by following taxonomic literature of [21], [22]. Identified specimens were further confirmed by comparing them with reference housed collection of National Insect Museum, National Agricultural Research Centre, Islamabad, Pakistan.

Relative percentage abundance for species of the family was also calculated.

\section{Results and Disscussions}

Total collected specimens comprising of five species under three genera of three subfamilies. The subfamilies explored were Licininae, Carabinae and Brachininae. In sub-family Licininae, three species belonging to one genus (Chlaenius) were collected, under sub-family Carabinae and Brachininae one species under each genus Carabus and Pheropsophus was collected. The relative percentage abundance of the sub-families of Carabidae was calculated from each locality of the district Poonch (Table. I).

\subsection{Sub-family Carabinae}

Carabus cashmirensis Redtenbacher, 1844

Material examined

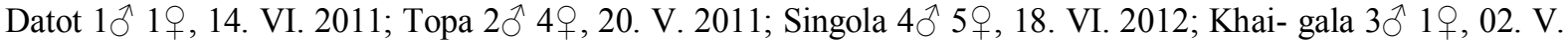

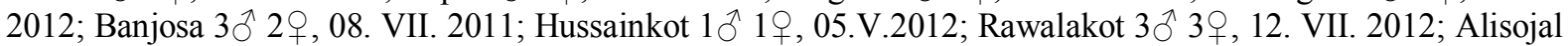

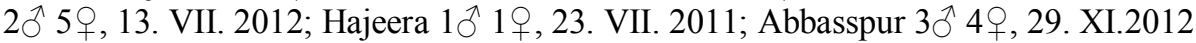

\section{Description}

Colour black rather dull, head narrow and smooth in front, surface finally wrinkled, eyes prominent, tooth of the mentum triangular; pro thorax slightly transverse, convex and wider than the head, elytra elongate and oval in shape extending up to the tip of abdomen. Elytra with irregular pits apex not finely granulate, pro tarsi undiluted; average body length $35 \mathrm{~mm}$.

\subsection{Sub-family Brachininae}

\section{Pheropsophus sobrinus Dejean, 1826}

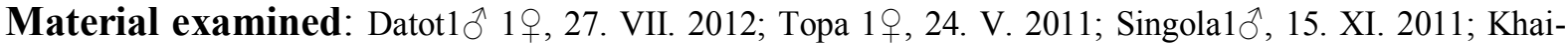

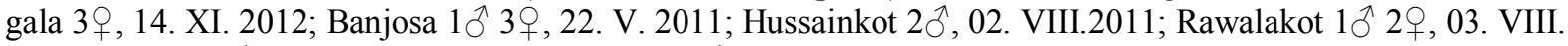
2012; Hajeera 1ठ 2ᄋ, 06. VII. 2011; Abbasspur 1ふึ, 12. XI. 2011.

\section{Description}

Mouth parts hypognathous, tooth of the mentum normal, antennae length up to $11 \mathrm{~mm}$, eyes prominent, head and thorax of same size; prothorax widened interiorly with a median line, pro legs and meso legs are of same size, femur more robust and stout, elytra black with three yellow bands, no pits on elytra, elytra reaching up to third last segment of the abdomen; average body length $19 \mathrm{~mm}$.

\subsection{Sub-family Licininae \\ Genus: Chlaenius \\ Chlaenius laticollis Say, 1823}


Material examined: Datot $1 \hat{\jmath} 2 q$, 05. XII. 2011; Topa 1ð 2q, 09. V. 2012; Banjosa 2+ , 01.X.2012;

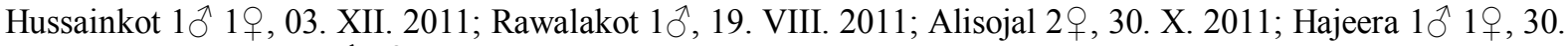
VII. 2012; Abbasspur 1ठ 2ᄋ, 14. VIII. 2012.

\section{Description}

Tooth of the mentum triangular, antennae $5.5 \mathrm{~mm}$ long; thorax wider than head and with out median line, colour of legs yellow, hind pair of leg larger than pro leg in size, elytra reaching up to the tip of abdomen with regular intervals; body flat, size ranging from $9-9.5 \mathrm{~mm}$.

\section{Chlaenius quadricolar Oliver, 1790}

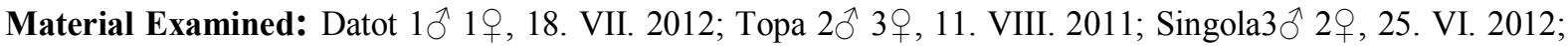
Khai- gala $3 \circ$ 3 $\hat{\jmath}, 21$. V. 2011; Banjosa $3 \hat{\jmath} 2$ ㅇ, 04. IX.2012; Hussainkot 2ㅇ, 09. X. 2012; Rawalakot $5 \hat{\jmath} 4$,

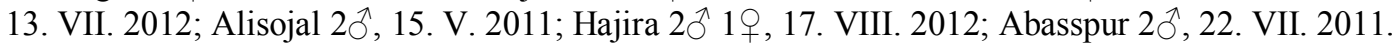

\section{Description}

Antennae 3-3.5 mm long, mouth parts hypognathous, tooth of the mentum triangular, eyes prominent; thorax large and wider than head, femur robust as compared to tibia and tarsi, elytra reaching to the tip of abdomen with regular intervals; body colour black, body length ranging up to $14 \mathrm{~mm}$.

\section{Chlaenius hamifer Chaudoir, 1856}

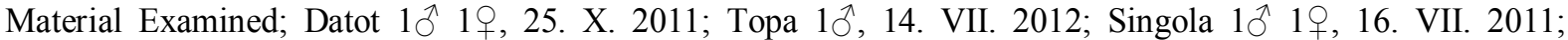

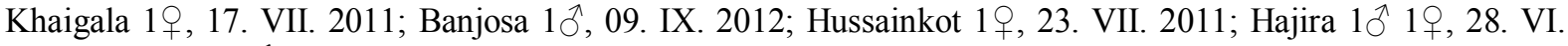
2011; Abasspur 2ふ, 18. VII. 2011.

\section{Description}

Tooth of the mentum triangular; thorax wider and longer than head, femur wide and robust with legs having pale yellow colouration, elytra reaching to the tip of abdomen with regular intervals, yellow bands on the tip of both elytra; body colour observed to be bright green, body size $19 \mathrm{~mm}$.

Sub-family Licininae yielded highest percentage however sub-family Brachininae yielded lowest percentage. Relative percentage abundance of species from each locality was also prepared and Carabus caschmirensis yielded highest and Chlaenius hamifer yielded lowest percentage. Among these species the most abundant species was Carabus caschmirensis (37\%) followed by Chlaenius quadricolar (27\%), Pheropsophs sobrinus (13\%), Chlaenius laticollis (12\%), and then Chlaenius hamifer (8\%). Carabid species diversity was higher in peak summer, found abundant in samples taken from litter and agricultural fields while lowest in areas near constructions. Carabid bettles considered as bio control agent of different crop pests and polyphagus on wide variety of plants [23], [24], [25]. During our study carabid collected from the agricultural fields have very low weed infestation due to their predation on weed seeds [26] intercropping enhance the beneficial role of carabid bettles. [27] suggested that carabid bettles are evaluated as potential control agent of economically important arthropods in forest and agricultural ecosystems.

\section{Conclusions}

From these results it is inferred that further entomological investigations of carabid bettles can be conducted by using different sampling methods for the description of their ecological services as bio control agent and predatory status, their feeding behavior and abundance of species from study area.

\section{Acknowledgment}

The first author offers the great sense of gratitude towards Prof. Dr. Rafique Khan for supervision and beloved Parents for their unconditional love support and co-operation at every stage during study.

\section{References}

[1] Ball, G. E. and T. L. Erwin, A taxonomic synopsis of the tribe Loricerini (Coleoptera: Carabidae), Can. J. Zool., 47, 1969, 877907.

[2] H. U. Thiele, Carabid beetles in their environments. A study on habitat selection by adaptation in physiology and behavior (Springer-Verlag, Berlin, Germany, 1977). 369 p.

[3] T. Magura,., B. Tothmeresz, and Z. Bordan, Effects of nature management practice on carabid assemblages (Coleoptera: Carabidae) in a non-native plantation, Biol. Conserv., 93, 2000, 95-102

[4] N. A. Melnychuk, O. Olfert, B. Youngs, and C. Gillott, Abundance and Diversity of Carabidae (Coleoptera) in different farming systems, Agric. Ecosyst. Environ., 95, 2003, 69-72.

[5] J. Niemela, J. Kotze, A. Ashworth, P. Brandmayr, K. Desender, T. New, L. Penev, M. Samways, and J. Spence, The search for common anthropogenic impacts on biodiversity: a global network, J. Insect Conserv., 4, 2000, 3-9.

[6] T. Magura, V. Kodobocz, and B. Tothmeres, Effects of habitat fragmentation on carabids in forest patches, J. Biogeog., 28, 2001, $129-138$

[7] J. Rainio and J. Niemela, Ground beetles (Coleoptera: Carabidae) as bioindicators, Biodivers. Conserv., 12, 2003, 487-506. 
[8] J. G. Lundgren, Ground beetles as weed control agents: effects of farm management on granivory, Am. Entomol., 51, 2005, 224226.

[9] M. Liebman, and E. R. Gallandt, Many little hammers: Ecological approaches for management of crop-weed interactions. in ecology in agriculture, (San Ddiego: Academic press, 1997)..

[10] M. Lagisz, P. Kramarz, R. Laskowski, and M. Tobor, Population parameters of the beetle Pterostichus oblongopunctatus F. from metal contaminated and reference areas, Bull. Environ. Contamination Toxicol., 69, 2002, 243-249.

[11] D. Stone, P. Jepson, and R. Laskowski, Trends in detoxification enzymes and heavy metal accumulation in ground beetles (Coleoptera: Carabidae) inhabiting a gradient of pollution, Comp. Biochem. Physiol., 132, 2002, 105-112.

[12] G. L. Lovei, and K. D. Sunderland, Ecology and behavior of ground beetles (Coleoptera: Carabidae). Annu. Rev. Entomol., 41, 1996, 231-256.

[13] R. G. Thompson, A synoptic list of the described ground beetle larvae of North America (Coleoptera: Carabidae), Proc. Biol, Soci., Washington, 90, 1977, 99-107.

[14] H. Goulet, Contributions of characters of larvae to systematics of Carabidae. Carabid beetles, their evolution, natural history, and classification, The Hague, 1977, 205-208.

[15] D. K. Nikolai, and P. D. Lyubomir, The ground beetles (Coleoptera: Carabidae) of south Dobrudzha, Bularia, Acta. Zool. Bulg., 58 , 2006, 147-180.

[16] S. Sakine, and L. L. Martin, Biodiversity of Carabidae beetles (Coleoptera: Carabidae) from crops in Turkey. Proc. Entomol. Soci., Washington, 111, 2009, 326-334.

[17] H. Ghahari, S.S. Avgin, and H. Ostovan, Carabid beetles (Coleoptera: Carabidae) collected from different ecosystems in Iran with new records, Turk. Entomol. Derg., 34, 2010, 179-195.

[18] S. Kamaluddin, and S. N. Hashmi, Redesription of Calosoma orientale Hope. (Coleoptera: Carabidae) with internal aspects of alimentary, male and female reproductive organs from Pakistan. Proc. Pak. Cong. Zool., 17, 1997, 73-79.

[19] S. N. Hashmi, S. Kammuldin, and S. Z. Hussain, Revision of the genus Colosoma weber (Coleoptera: Carabidae) with two new species from Pakistan with their cladistic relationships. International J. Biol. Biotechnol., 2, 2005, 259-272.

[20] E. W. Richard, Peterson: a field guide to beetles (Houhton Mifflin company, New York, 1983).

[21] H. E. Andrews, 1929. The fauna of British India. Coleoptera (Carabidae) (Today and Tomarrow Printers and Publishers, 1929).

[22] P. M. Choate, Manual for the identification of Ground beetles (Coleoptera: Carabidae) (including tiger beetles) of Florida. Depart. Entomol., 2001.

[23] T. H. Coaker, and D. A. Williams, The importance of some Carabidae and Staphylinidae as predators of the cabbage root fly Erioischia brassicae (Bouchr), Entomol. Exp. Appl., 6, 1963, 156-164.

[24] J. P. Dempster, The control of Pieris rapae with DDT. 1. The natural mortality of the young stages of Pieris. J. Appl. Ecol., 4, 1967, 485-500.

[25] P. A. Chiverton, Predation of Rhopalosiphum padi (Homoptera: Aphididae) by polyphagous predatory arthropods during the aphids' pre-peak period in spring barley, Ann. Appl. Biol., 3, 1987, 257-269.

[26] G. Armstrong, and R. G. McKinlay, Vegetation management in organic cabbages and pitfall catches of carabid beetles, Agriculture Ecosyst. Environ., 64, 1997, 267-276.

[27] D. L. Epstein, R. S. Zack, J. F. Brunner, L. Gut, and J. J. Brown, Ground beetle activity in apple orchards under reduced pesticide management regimes, Biol. Control., 21, 2001, 97-104. 


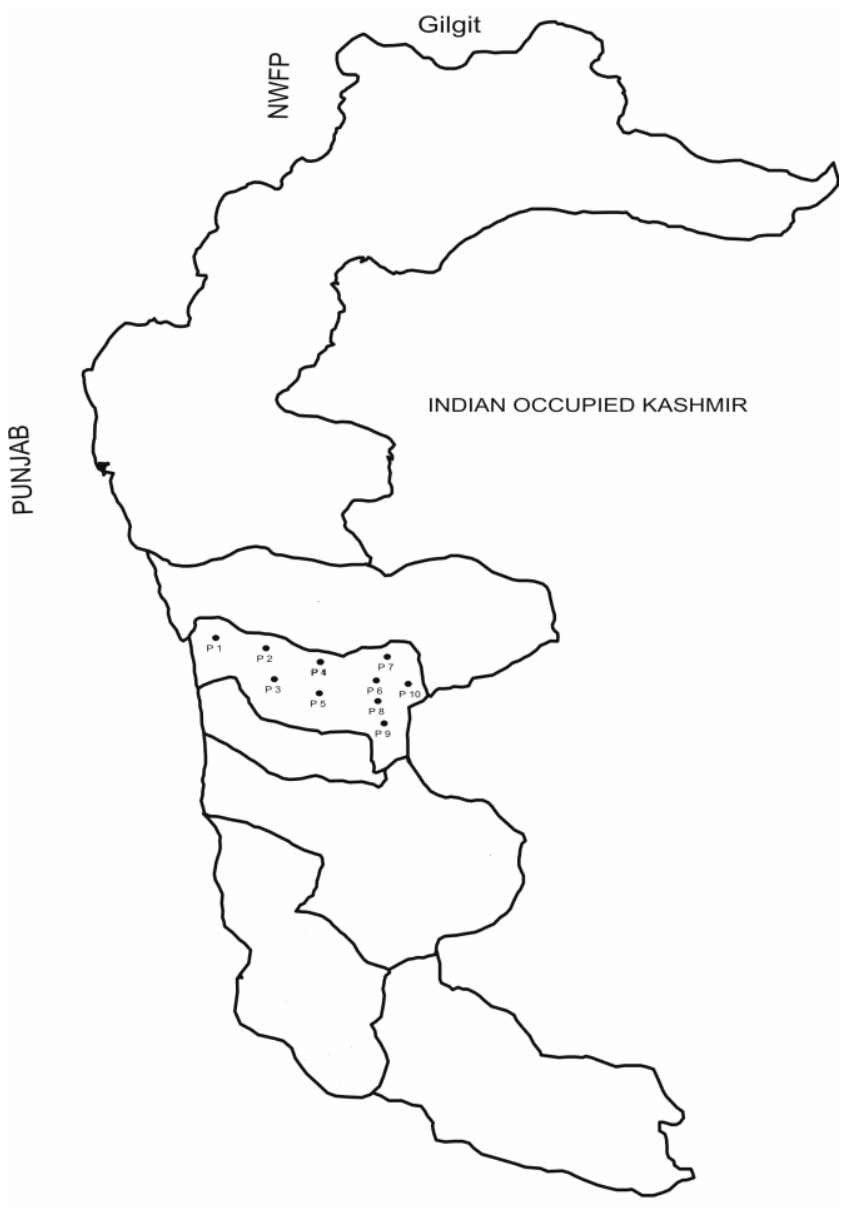

\begin{tabular}{|l|l|}
\hline $\begin{array}{l}\text { Distric } \\
\mathrm{t} \\
\text { Poonc } \\
\mathrm{h}\end{array}$ & $\begin{array}{l}\text { Locality } \\
\text { visited }\end{array}$ \\
\hline P1 & Datot \\
\hline P2 & Topa \\
\hline P3 & Rawalakot \\
\hline P4 & Singola \\
\hline P5 & Hussainkot \\
\hline P6 & Bunjosa \\
\hline P7 & Khaigala \\
\hline P8 & Alisojal \\
\hline P9 & Hajira \\
\hline P10 & Abasspur \\
\hline
\end{tabular}

Fig. I: Map of Azad Kashmir

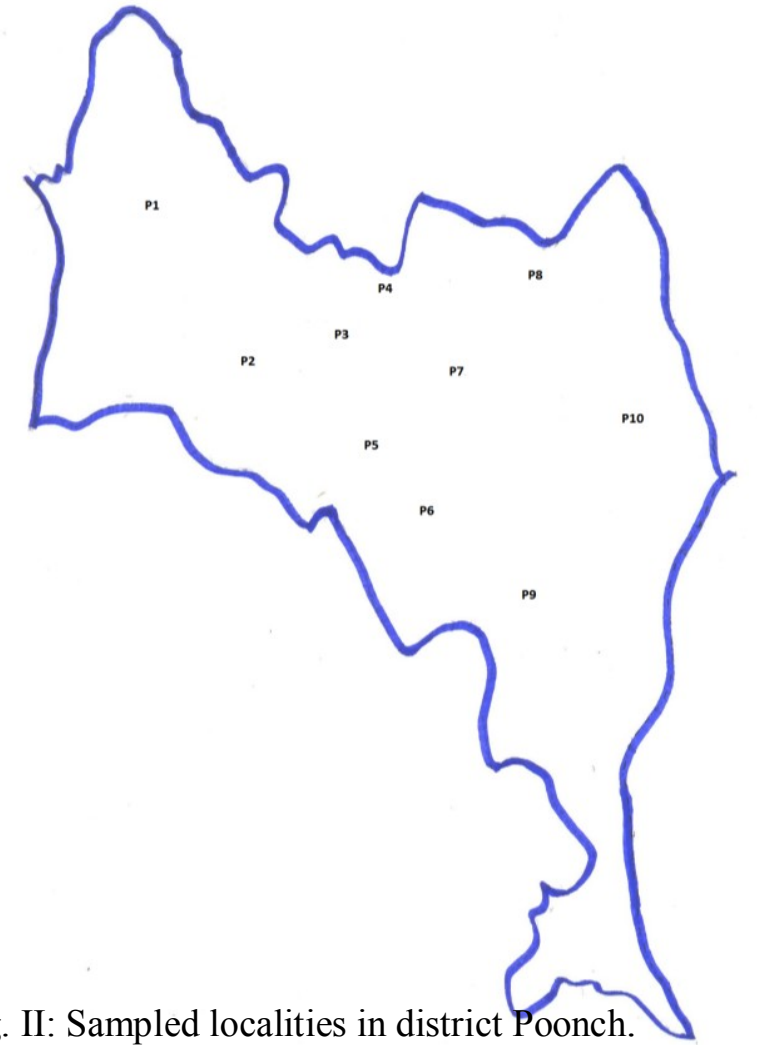


Table. I: Relative percentage abundance of species of Carabidae recorded from district Poonch.

\begin{tabular}{|c|c|c|c|c|c|c|c|c|c|c|c|c|}
\hline 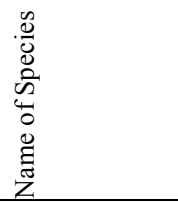 & 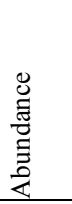 & 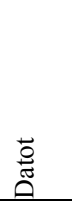 & 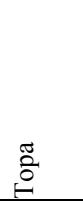 & $\begin{array}{l}\frac{\pi}{0} \\
\stackrel{0}{0} \\
\text { औ }\end{array}$ & 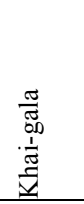 & 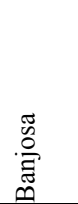 & $\begin{array}{l}\overrightarrow{0} \\
\text { 泀 } \\
0 \\
0 \\
0 \\
0\end{array}$ & 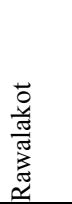 & $\begin{array}{l}\bar{\sigma} \\
\frac{\pi}{2} \\
\frac{0}{2}\end{array}$ & : & 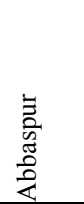 & 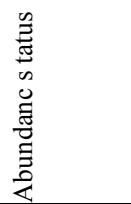 \\
\hline $\begin{array}{l}\text { Carabus } \\
\text { caschmirensis }\end{array}$ & 37.5 & 1.388 & 4.166 & 6.25 & 2.777 & 3.472 & 4.166 & 4.166 & 4.861 & 1.388 & 4.861 & Domonant \\
\hline $\begin{array}{l}\text { Chlaenius } \\
\text { quadricolar }\end{array}$ & 27.77 & 1.388 & 3.472 & 2.777 & 4.166 & 3.472 & 1.388 & 6.25 & 1.388 & 2.083 & 1.388 & $\begin{array}{l}\text { M. } \\
\text { Dominant }\end{array}$ \\
\hline $\begin{array}{l}\text { Pheropsophs } \\
\text { sobrinus }\end{array}$ & 13.88 & 1.388 & 0.694 & 0.694 & 2.083 & 2.777 & 1.388 & 2.083 & - & 2.083 & 0.694 & Moderate \\
\hline $\begin{array}{l}\text { Chlaenius } \\
\text { laticollis }\end{array}$ & 12.5 & 2.083 & 1.388 & - & - & 1.388 & 1.388 & 1.388 & 1.388 & 1.388 & 2.083 & Low \\
\hline $\begin{array}{l}\text { Chlaenius } \\
\text { hamifer }\end{array}$ & 8.333 & 1.388 & 0.694 & 1.388 & 0.694 & 0.694 & 0.694 & - & - & 1.388 & 1.388 & Low \\
\hline
\end{tabular}

